Responsible Management Research: A Senior Scholar Legacy in Doctoral Education

\author{
Peter McKiernan \\ University of Strathclyde, UK
}

Anne S. Tsui

University of Notre Dame, USA

\begin{abstract}
Author's Note
Thanks are due to Jon Billsberry and Ken Starkey for comments on an earlier draft.
\end{abstract}




\section{Responsible Management Research: A Senior Scholar Legacy in Doctoral Education}

Harley's (2019) encouragement of senior scholars to play an influential role in the conduct of management research is vital. His epistle multiplies the voices convicting this scholarship for its lack of rigour and relevance. Many scholars find the last 30 years of research to have failed both its internal standards (Bedeian, Taylor, \& Miller, 2010; Honig, Lampel, Siegel, \& Drnevich, 2014; Tsui, 2016) and its external expectations (Aguinis, Suárez-González, Lannelongue, \& Joo. 2012; Ghoshal, 2005; Tsui, 2015; Harley \& Cornelissen, 2018). This vociferous 'hue and cry' for a new pathway invites science to selfcorrect, with the recent responsibility turn demanding that greater attention be paid to producing credible and useful research findings.

This turn may be gaining traction. For instance, the Open Science Framework (cos.io) offers eight standards of transparency and openness to improve the quality and reliability of research studies. Focusing primarily on natural sciences, it now has over 10,000 scholars engaging in some form of transparency practice. In social science, the community for Responsible Research in Business and Management (www.rrbm.network) provides seven guiding principles for the production of both reliable and useful knowledge. Presently, it has over 1000 signatories that endorse its principles, and pledge to practice and promote responsible research. In parallel, top tier journals in the domain are re-defining rigour (e.g., Meyer, Witteloostuijn, \& Beugelsdijk, 2017), requiring data sharing and offering the option of pre-registration of hypotheses and study design (Lewin, et al., 2016). There is a call for more replication studies (Ethiraj, Gambardella, \& Helfat, 2016) and more indigenous scholarship to ensure that high quality research meets local conditions and needs (Van de Ven, Meyer \& Jin, 2018). In this rejoinder, we call upon senior scholars to leave a legacy by helping a new generation of scholars to internalize the higher calling of science; to learn the 
intricate relationship between science and society; and, how to become responsible public servants of scientific knowledge.

The responsibility of science to society

Since the beginning of modern science, there has been a constant questioning of the utility of science to society. Almost 50 years ago, peace researcher Marek Thee remarked:

"Yet, in few fields of scientific enquiry are the social consequences of new discoveries and technologies thoroughly studied and clearly anticipated...social science (on the other hand) is inclined to build castles of theory and is seldom action-orientated." (Thee, 1972: 367)

Thee's cry to scientists stressed that their social responsibility was as crucial as at any point in world history. Research needs a free debate within the scientific community and this community needs an ongoing dialogue with society. He suggested that scientists sign the equivalent of the medics' Hippocratic Oath - stressing that science would not be used to harm human beings but, be devoted to the betterment of life, freedom and peace, inter alia ${ }^{1}$. This notion is reflected in the case for the professionalisation of management:

"What we know to be true is that the pace of discovery and creative progress rapidly accelerated in medicine once it became a profession." (Nohria \& Khurana, 2008: 73)

Most scientific training in management begins in doctoral programmes. Here, research's broader role is often overlooked for a narrow focus on method and technique. Many current designs fit the 'top journal article' world into which junior scholars enter. Kuhn (1996) asserted that breakers of paradigms would come from such scholars; people who enter the profession with great idealism and a passion for making a difference in the world, and who are not fully socialized into the dominant way of thinking. If many seasoned academics

\footnotetext{
${ }^{1}$ e.g., see the Hippocratic Oath for Managers at Harvard Business School
} 
and their deans feel intellectually trapped in 'Plato's cave'2, or by their own received history (Bridgman et al, 2016) or by the treadmill of evaluation exercises then, a new generation of doctoral students, who can see the light of the real world might be the interrogative force required for a better social contract.

A generational remedy in doctoral education

Irreversible change to the dominant logic is unlikely to come from scholars in the "tenure-track", trapped by the perenniality of top journal expectation. But senior faculty (especially the emeriti) who are freed from the publication pressure could provide a force for generational change. For instance, they might imbue doctoral students with a deeper appreciation of the philosophical underpinnings of social science and a thorough understanding of the responsibility of the scientist to society. These inputs would produce better and more useful research that, in turn, might lead to greater stakeholder respect for the science emanating from business schools. These sentiments were expressed in prior generations by educational giants like Humboldt ${ }^{3}$, who stressed the ethical precision of science and the sharing of knowledge; and, by Newman ${ }^{4}$ who advocated the promotion of research and its output in isolation from religious zeal. Both looked to science for the betterment of society. Nowhere is this message more important than in the education and training of new scientists in doctoral programmes.

\footnotetext{
${ }^{2}$ Where prisoners in a cave face a wall and their chains do not allow them to turn around. They watch shadows on the wall from puppets projected from the light of the fire behind them and think that what they see represents the truth; but this is an illusion. The real truth is experienced by those who can escape the cave, see the light and experience reality (Plato, The Allegory of the Cave, Republic).

${ }^{3}$ Alexander von Humboldt was a 18/19 century German academic who became one of the most famous educators in Europe and America. One of his most respected contributions was his precise and systematic measurement during his introduction of modern science to a variety of subject domains. His sponsorship of young academics during his life, and from his foundation thereafter, is legendary.

${ }^{4}$ John Henry Newman was a $19^{\text {th }}$ century Anglican priest, literary figure, theologian and educator who converted to Catholicism and became a Cardinal in the Church (he is now a Saint). When shaping the early days of the Catholic University of Ireland (now UCD), he sought the international intellectual legitimacy of his higher educational institution through the separation of research from the influence of religious authority.
} 
Toward a deeper understanding of social science and scientific responsibility

Presently, the sustainability of both the social and natural world is at risk. Human actions have influenced our nature in profound ways, including the dangerous depletion of natural resources and international social and economic inequality. An intriguing puzzle concerns human nature: Why do some humans pursue self-interests at the expense of others and why are some willing to sacrifice future survival for present pleasure? Science can interrogate the interaction of humans and the natural world and solve their puzzles through the meticulous execution of both theory and method, so that its explanations are valid and trusted. Is producing reliable results the limit of the responsibility of science?

In a timeless essay, Merton $(1942 ; 1973)$ asserted that science exists in the institutional structure of a society. Universal standards in assessing the validity of scientific claims, freedom to pursue science, scientific finding as common property, self-regulation and peer policing of scientific conduct are parts of the normative structure of science. This structure covers both the rights and the responsibilities of scientists. But, should or can science be independent from the expectations of society? Should scientists be expected to offer advice on policies? What responsibility does the scientist have on potential consequences to society due to errors in scientific discovery (Douglas, 2009)? Thoughtful discussions of these questions should be part of the education of nascent scientists.

Within the domain of management research, most journal policy instructs authors to conclude a paper by discussing the implications of their research findings for managers or for practice. Many authors find this requirement difficult because they did not think about these recipients in their study design (Bartunek \& Rynes, 2010). Their focus was on meeting the expectations of the editors and reviewers and not on the needs of managers or policy makers. It appears that scientists in business schools are responsible only to their scientific community, since most are held accountable for the academic and not the social impact of 
their research. If so, why do editors and reviewers insist on a discussion of the practical implications? Should authors be expected to discuss implications for practice based on one study? Given the dynamic, complex, reactive and contextualized nature of social phenomena, is replication ever possible in social science? Indeed, how many replications are enough to establish a 'truth'? Doctoral education should include deep thinking and intense debating of these thorny questions.

Beyond replication, Kuhn (1996) asks how scientific progress is achieved. Some top journals in management emphasize theoretical novelty in each submission. According to Kuhn, theoretical novelty happens once in a rare while and most scientific progress comes from incremental work within the normal science period between paradigm shifts. Is seeking theoretical novelty good for scientific progress and discovery? If knowledge is contextual (Polanyi, 2009; Tsui, 2018), should we not welcome context-specific research and knowledge as much as discovering natural law or universal law in social science? - Further, as one philosopher has claimed, "social scientists are agents of change whether they want to be or not" (Risjord, 2014: p 52). This role as change agents of the social world comes from our choice of a) research topics; b) methods of our inquiry; and, c) assumptions of human nature (self-interest only or a capacity for other-interests) that underlie our theory. Subjects may inadvertently live up to the scientists' view of reality through observation, interaction, or measurement. But scientists are not value-free agents. Value-neutrality is a noble goal but it is hard to achieve in scientific work. What is objectivity in science and how can it be achieved when value-laden humans are involved in the scientific inquiries?

The value-free ideal in the philosophy of science is still a controversial topic (Tsui, 2016). The original intent was to protect science from the interference of religion and politics and to ensure science benefited all humanity and not just the privileged few. Later, valueneutrality was interpreted as an academic freedom for scientists working in university 
settings (Bok, 2009). Can there be true academic freedom within an institutional structure with priorities that may differ from the scientific community and that has control over resource allocation? If values are unavoidable, what values should guide scientific activities and what values should be avoided? In general, how would an understanding of epistemology, ontology, and other philosophy of science concepts help or hinder us in our research?

A deep understanding of these topics would prepare doctoral students to become better social scientists; to live up to the expectations of society; and, to become responsible public servants of knowledge. The wellbeing of society is improved markedly through the accumulation of credible and useful knowledge that informs management practices and develops responsible leaders for a world in need. We call upon senior scholars to confront these questions and contribute to this generational education by both designing and teaching their schools' doctoral programme.

\section{References}

Aguinis, H., Suárez-González, I., Lannelongue, G., \& Joo, H. 2012. Scholarly impact revisited. Academy of Management Perspectives, 26(2): 105-132.

Bartunek, J.M., \& Rynes, S. I. 2010. The Construction and Contributions of "Implications for Practice": What's in them and what might they offer? Academy of Management Learning and Education, 9(1): 100-117

Bedeian, A. G., Taylor, S. G., \& Miller, A. N. 2010. Management science on the credibility bubble: Cardinal sins and various misdemeanors. Academy of Management Learning \& Education, 9(4): 715-725.

Bok, D. 1986. Beyond the ivory tower: Social responsibilities of the modern university. Cambridge, Mass: Harvard University Press. 
Bridgman, T., Cummings, S., \& McLaughlin, C. 2016. Restating the case: How revisiting the development of the case method can help us think differently about the future of the Business School. Academy of Management Learning \& Education, 15(4): 724-741.

Community for Responsible Research in Business and Management. 2017. A vision of responsible research in business and management; Striving for credible and useful knowledge. Retrieved December 3, 2018, from https://rrbm.network/wpcontent/uploads/2017/09/White_Paper.pdf

Douglas, H. E. 2009. Science, Policy, and the Value-Free Ideal: University of Pittsburgh Press.

Ethiraj, S. K., Gambardella, A., \& Helfat, C. E. 2016. Replication in strategic management. Strategic Management Journal, 37(11): 2191-2192.

Ghoshal, S. 2005. Bad management theories are destroying good management practices. Academy of Management Learning \& Education, 4(1): 75-91.

Harley, B. 2019. Confronting the crisis of confidence in management studies: Why senior scholars need to stop setting a bad example. Academy of Management Learning \& Education. [DOI: to follow]

Harley, B., \& Cornelissen, J. P. In press. Reframing rigor as reasoning: Challenging technocratic versions of rigor in management research. Research in the Sociology of Organizations. [DOI: to follow]

Honig, B., Lampel, J., Siegel, D., \& Drnevich, P. 2014. Ethics in the production and dissemination of management research: Institutional failure or individual fallibility? Journal of Management Studies, 51(1): 118-142.

Khurana, R., \& Nohria, N. 2008. It's time to make management a true profession. Harvard Business Review, 86(10): 70. 
Kuhn, T. S. 1996. The structure of scientific revolutions, $3 r d$ ed. Chicago, IL, US: University of Chicago Press.

Lewin, A. Y., Chiu, C.-Y., Fey, C. F., Levine, S. S., McDermott, G., Murmann, J. P., et al. 2016. The critique of empirical social science: New policies at management and organization review. Management and Organization Review, 12(4): 649-658.

Merton, R. K. 1973. The normative structure of science. In R. K. Merton \& N. W. Storer (Eds.), The Sociology of Science : Theoretical and Empirical Investigations. Chicago IL: University of Chicago Press.

Meyer, K. E., Van Witteloostuijn, A., \& Beugelsdijk, S. 2017. What's in a p? Reassessing best practices for conducting and reporting hypothesis-testing research. Journal of International Business Studies, 48(5): 535-551.

Polanyi, M. 2009. The tacit dimension. Chicago: University of Chicago Press.

Risjord, M. 2014. Philosophy of social science: A contemporary introduction. New York: Routledge.

Thee, M. 1972. The scientist's role in society: An outline of a strategy. Bulletin of Peace Proposals, 3(4): 367-370.

Tsui, A. 2015. Reconnecting with the business world: socially responsible scholarship. Global Focus, 9(1): 36-39.

Tsui, A. 2016. Reflections on the so-called value-free ideal: A call for responsible science in the business schools. Cross Cultural and Strategic Management, 23(1): 4-28.

Tsui, A. 2018. Commentary on 'Opportunities and Challenges of Engaged Indigenous Scholarship' (Van de Ven, Meyer, \& Jing, 2018). Management and Organization Review, in press.

Van De Ven, A., Meyer, A., \& Jing, R. (2018). Opportunities and challenges of engaged indigenous scholarship. Management and Organization Review, 14(3): 449-462. 